\title{
Overexpression of human IGF-II mRNA in the brain of transgenic mice modulates IGFBP-2 gene expression in the medulla oblongata
}

\author{
C M A Reijnders ${ }^{1}$, J G Koster ${ }^{1,2}$ and S C van Buul-Offers ${ }^{1}$ \\ ${ }^{1}$ Department of Metabolic and Endocrine Diseases, University Medical Center Utrecht, PO Box 85090, NL-3508 AB Utrecht, The Netherlands \\ ${ }^{2}$ Department of Neonatology, University Medical Center Utrecht, PO Box 85090, NL-3508 AB Utrecht, The Netherlands \\ (Requests for offprints should be addressed to S C Van Buul-Offers, Room KE 03·139·2, PO Box 85090, NL-3508 AB Utrecht, The Netherlands; Email: \\ S.vanBuul@azu.nl)
}

\begin{abstract}
The insulin-like growth factors, IGF-I and IGF-II, and their binding proteins play an important role in the growth and development of the central nervous system. In the brain, colocalization of IGFs and IGFBPs often occurs, suggesting that IGFBPs can modulate IGF action. In one strain of our human (h)IGF-II transgenic mice, which carry an hIGF-II transgene driven by the $\mathrm{H}-2 \mathrm{~K}^{\mathrm{b}}$ promoter, we found overexpression of hIGF-II in the brain, as measured by Northern blot analysis. To clarify the localization and influence of the hIGF-II transgene on different components of the GH-IGF axis in the brain, we studied the expression pattern of the hIGF-II transgene, endogenous IGF-I and IGF-II, and IGFBP-2, -3 and -5 in the brain of prepubertal 4-week-old mice, using nonradioactive in situ hybridization. We found that the hIGF-II transgene is exclusively expressed in neurons of the piriform cortex, the cerebral cortex, the medulla oblongata and the granular layer of the cerebellum. In general, this pattern is comparable to the expression pattern of endog-
\end{abstract}

enous IGF-I, with a few exceptions: there is no expression of IGF-I in the granular layer of the cerebellum, whereas the Purkinje cells of the cerebellum and thalamus both express IGF-I but no hIGF-II transgene. This hIGF-II transgene expression pattern contrasts markedly with endogenous IGF-II expression, which is mainly located in nonneuronal cells such as the meninges and choroid plexus, and in some nuclei of the medulla oblongata. The hIGF-II transgene affects neither endogenous IGF-I and IGF-II expression, nor the expression of IGFBP-3, which is located in the choroid plexus. Although the hIGF-II transgene is expressed in neuronal structures similar to IGF-I and IGFBP-5, it is not able to regulate IGFBP-5 expression, as has previously been reported for IGF-I. In the medulla oblongata, the IGFBP-2 expression level showed 10-fold upregulation by the transgene, suggesting a modulating role for IGFBP-2 at the hIGF-II transgene action in this region.

Journal of Endocrinology (2004) 182, 445-455

\section{Introduction}

The insulin-like growth factors, IGF-I and IGF-II, and their binding proteins (IGFBPs) are widely expressed and temporally and spatially distributed in the central nervous system, suggesting that they play an important role during brain development (D'Ercole et al. 1996, Walter et al. 1997, Naeve et al. 2000). It has been generally accepted that IGF-I is predominantly expressed in neuronal cells in the adult, whereas the regional distribution of IGF-II has been shown to be mainly restricted to the neuroepithelial cells of the meninges and choroid plexus (Stylianopoulou et al. 1988, Bondy et al. 1992, Lee et al. 1993, Logan et al. 1994). In one strain of our human (h)IGF-II transgenic mice, which carry a transgene driven by the $\mathrm{H}-2 \mathrm{~K}^{\mathrm{b}}$ promoter, we found overexpression of hIGF-II mRNA in the brain, as measured by Northern blot analysis (van Buul-Offers et al. 1995). This was surprising, since this promoter is usually not expressed in the brain (Drezen et al. 1992). Ectopic expression of transgenes has been reported previously. Swanson et al. (1985) showed that growth hormone $(\mathrm{GH})$ under the control of the metallothionein (MT) promoter is expressed in specific brain areas, where GH and MT are usually not expressed. In contrast, IGF-I transgenic mice, where the transgene is driven by the MT or IGF-II promoter, show specific expression of the IGF-I transgene in a similar pattern as the endogenous IGF-I gene (Ye et al. 1996). In the light of these discrepancies, we first investigated whether the regional expression of the IGF-II transgene coincides with that of endogenous IGF-I or IGF-II.

During brain development, IGFBPs are often coexpressed with IGFs, thus enabling IGFBPs to modulate the actions of the IGFs (Leventhal et al. 1999). So far, it has been shown that IGFBP-2 is mainly colocalized with IGF-II in the meninges and choroid plexus (Logan et al. 1994) 
and with IGF-I in neuronal structures (Lee et al. 1993), whereas IGFBP-5 has been shown to colocalize with IGF-I or in the vicinity of IGF-I-producing neurons, suggesting that both IGFBP-2 and -5 can modulate the action of the IGFs (Bondy \& Lee 1993). In addition, it has been shown that IGFBP-5 mRNA expression is upregulated by IGF-I in the brain of pubertal 6-week-old IGF-I-transgenic mice (Ye et al. 1996). By contrast, hypoxia or brain injuries cause an increased expression of both IGF-II and IGFBP-2 (Beilharz et al. 1995, Guan et al . 1996, Walter et al. 1997).

In a previous study, we found upregulation of IGF-I expression in the growth plate of hIGF-II-transgenic mice in comparison with normal mice (Smink et al. 2002). In addition, IGFBP-2 and -5 were increased in the spleen and thymus of these mice, whereas IGFBP-3 was increased exclusively in the spleen (Smink et al. 1999). Since nothing is known about the regulation of these binding proteins by IGF-II in the brain, we also studied the modulating action of the IGF-II transgene on the expression pattern of IGFBP-2, -3 and -5 , as well as of IGF-I, by using nonradioactive in situ hybridization.

\section{Materials and Methods}

\section{Materials}

All restriction enzymes and modifying enzymes were purchased from Roche Molecular Biochemicals (Mannheim, Germany), as well as digoxigenin-UTP, antidigoxigenin Fab fragments, nitro-blue tetrazolium chloride, 5-bromo4-chloro-3-indolyl phosphatase and blocking reagent. Nylon membranes were purchased from Schleicher \& Schuell (Dassel, Germany).

Mouse IGFBP-2, -3 and -5 cDNAs were kindly provided by Prof. Dr SLS Drop and Dr JW van Neck (Department of Pediatrics, Subdivision of Pediatric Endocrinology, Sophia Children's Hospital, Erasmus University, Rotterdam, The Netherlands).

Polyvinylalcohol was obtained from Aldrich (Milwaukee, WI, USA). Euparal mounting medium was purchased from Chroma Gesellschaft (Schmid GmbH, Köngen, Norway).

\section{Animals}

hIGF-II transgenic mice were generated by introduction of a human IGF-II gene into FVB/N control mice, as described in detail by van Buul-Offers et al. (1995). The human IGF-II gene is controlled by the $\mathrm{H}-2 \mathrm{~K}^{\mathrm{b}}$ promoter and contains the small t-intron of SV40 as polyadenylation signal. Throughout the study, the line designated 5'-2 (Tg-II) was used for our experiments. As controls, normal $\mathrm{FVB} / \mathrm{N}$ mice were used. The animals were kept under standard laboratory conditions.

All animal experiments were in accordance with governmental guidelines for care and use of laboratory animals, and were approved by the Committee for Animal Research of the Medical Faculty, University of Utrecht.

\section{Synthesis of digoxigenin-labeled complementary RNA (cRNA) probes}

Standard RNA synthesis reactions using T7- or T3-RNA polymerase were carried out with digoxigenin-UTP as a substrate (Melton et al. 1984). cDNAs encoding human IGF-I (258 bp, containing exons 2 and 3) (Jansen et al. 1983) and human IGF-II (304 bp, SacII-Xhol fragment containing exons 7 ( $3^{\prime}$ part), 8 and 9 ( $5^{\prime}$ part)) (Jansen et al. $1985)$ and mouse IGFBP-2, -3 and -5 cDNAs, corresponding to amino-acid positions 98-258, 137-204 and 88-182 respectively (Schuller et al. 1993), as well as a cDNA encompassing the $1 \mathrm{~kb}$ BamHI-BamHI SV40 fragment (van Buul-Offers et al. 1995), were used as templates for the synthesis of antisense and sense digoxigenin-labeled RNA probes. All probes used were specific for the mRNAs analyzed. The human IGF-II probe detects both endogenous mouse IGF-II and the transgene (Smink et al. 1999). The SV40 fragment detects only the mRNAs of the transgene as verified by Northern blot analysis (van Buul-Offers et al. 1995). The use of both probes makes it possible to discriminate between endogenous and transgene IGF-II mRNAs (Smink et al. 1999, 2002). Probes were checked for cross-hybridization, using in situ hybridization on different types of mouse tissues (spleen, thymus and whole embryos) for the IGFBP probes (Smink et al. 1999, 2002, van Kleffens et al. 2001); and on spleen and growth plate cartilage for the IGF probes (Smink et al. 2002). The various probes displayed distinct expression patterns in these tissues. Northern blot analysis of different tissues using the same probes yielded bands of the expected sizes, verifying the correct identity of the probes (data not shown).

\section{Tissue preparation}

Mice were killed by decapitation after ether anesthesia at the age of 4 weeks, and the spleen and brain were dissected. For in situ hybridization, the spleen and brain were fixed in $4 \%(\mathrm{w} / \mathrm{v})$ formaldehyde (buffered in PBS, $\mathrm{pH} 6 \cdot 8-7 \cdot 2$ ) at $19{ }^{\circ} \mathrm{C}$ for $20 \mathrm{~h}$, washed in PBS and dehydrated through a series of ethanol. The fixed brain was cut rostral to the cerebellum (interaural coordinate $0 \mathrm{~mm}$ ) and the hippocampus (interaural coordinate $4 \mathrm{~mm}$ ) in three coronal blocks, and embedded in paraffin. Of each brain part, $5 \mu \mathrm{m}$ sections were cut, and every 50 th section was stained with methylene blue in order to verify the position of the sections within the brain of the different animals with the mouse brain atlas (Franklin \& Paxinos 1997). All sections were mounted onto RNase-free TESPA-coated (3-aminopropyltriethoxysilan) glass slides, dried overnight at $37{ }^{\circ} \mathrm{C}$ and stored at $4{ }^{\circ} \mathrm{C}$ until further use. Comparable sections of normal and transgenic brains 
were mounted on one slide and analyzed with an RNA probe. A second check of the position of each section was determined by staining with hematoxylin-eosin and cresyl violet (Kawamura \& Niimi 1972).

\section{Nonradioactive in situ hybridization}

Paraffin tissue sections of the spleen and brain $(5 \mu \mathrm{m})$ were dewaxed, hydrated, rinsed in PBS and treated with proteinase $\mathrm{K}(0 \cdot 1 \mathrm{U} / \mathrm{ml})$ for $30 \mathrm{~min}$ at $37^{\circ} \mathrm{C}$, and subjected to acetylation (Wilkinson 1992). Sections were rinsed in $2 \times$ SSC and kept in this solution until hybridization.

Hybridization was performed in a solution containing $50 \%$ formamide, $2 \times$ SSC, 1 Denhardt's solution, $1 \mu \mathrm{g} / \mu \mathrm{l}$ yeast RNA and 10\% dextran-sulfate and digoxigeninlabeled cRNA probe at a concentration of 500-1250 pg/ $\mu \mathrm{l}$ depending on the probe. Sections were hybridized overnight at $50{ }^{\circ} \mathrm{C}$ (hIGF-I), $53{ }^{\circ} \mathrm{C}$ (SV40 and IGFBP-2, -3, and -5 ) and $63^{\circ} \mathrm{C}$ (hIGF-II). After hybridization, sections were washed with $50 \%$ formamide in $2 \times \mathrm{SSC}$ at the same temperature as the hybridization temperature for $30 \mathrm{~min}$ and treated with RNase A $(1 \mathrm{U} / \mathrm{ml})$ for $30 \mathrm{~min}$ at $37^{\circ} \mathrm{C}$.

Subsequently, sections were rinsed in $2 \times$ SSC, treated with $10 \%$ lamb serum for $30 \mathrm{~min}$ and incubated with sheep antidigoxigenin Fab-fragments conjugated with alkaline phosphatase $(1: 500)$ for $2 \mathrm{~h}$ at $19^{\circ} \mathrm{C}$.

Chromogenesis was performed with $0.38 \mathrm{mg} / \mathrm{ml}$ nitroblue tetrazolium chloride and $0.19 \mathrm{mg} / \mathrm{ml}$ 5-bromo-4chloro-3-indolyl phosphatase in the presence of $6 \%(\mathrm{w} / \mathrm{v})$ polyvinylalcohol (De Block \& Debrouwer 1993), resulting in a blue precipitate. Sections were counterstained with nuclear fast red, dehydrated through a series of ethanol and mounted with Euparal.

Sense probes were used to investigate the level of nonspecific binding. The brains of three to five different animals of each strain were analyzed per mRNA of interest using in situ hybridization. The gene expression must be located in the cytoplasm, because mRNA is located in the cytoplasm. Positive signal is shown as a blue precipitate in the cytoplasm, whereas the nucleus is stained red.

\section{Quantification and statistics}

We first performed a semiquantitative screening of the glass slides. Two independent investigators scored blind all slides in a semiquantitative manner (-, no expression; +, expression).

Only for IGFBP-2 expression were differences between normal and hIGF-II transgenic mice found within the nuclei of the medulla oblongata. Therefore, quantitative analysis of IGFBP-2 expression was performed with the Image Pro Plus program (version 4.5) (Media Cybernetics Inc, Silver Spring, MD, USA). We defined an area of interest of $900 \times 900$ pixels $(900$ pixels $=500 \mu \mathrm{m})$ within the trigeminal nucleus. This nucleus is a very recognizable structure of the medulla oblongata. In this area, we measured the total IGFBP-2-positive pixels by color segmentation (histogram based) in the hIGF-II transgene mice $(n=5)$ and the FVB mice $(n=4)$. Student's $t$-test was used for statistical analysis. A $P$ value of $<0.05$ was considered statistically significant.

\section{Photography}

Bright-field photographs were made, using a gray filter and full light $(10.5 \mathrm{~V})$, with a microscope (Leica type DM-RD), a digital camera (automatic exposure) (Leica DC200) and Axio Vision 3.1 (Zeiss).

\section{Results}

\section{Specificity of the hIGF-II transgene probe}

Hybridization of the transgenic mice spleen, using either the hIGF-II transgene-specific antisense SV40 probe (Fig. 1A) or the IGF-II antisense probe (Fig. 1B), showed hIGF-II transgene expression in the white pulpa of the hIGF-II transgenic mice spleen. Since no transgenic or endogenous IGF-II expression was observed in the normal mice spleen using the same antisense probes (Fig. 1C and D), we considered that both probes could detect the hIGF-II transgene.

\section{IGF-II transgene expression in neuronal structures of the brain}

Analysis of endogenous IGF-II expression in normal mouse brain by nonradioactive in situ hybridization showed expression in the meninges (Fig. 2A) and in the simple cuboidal epithelium of the choroid plexus (Fig. 2D). In addition, IGF-II expression was observed in the vestibular (cerebellar) nucleus, the trigeminal nucleus, the interposed nucleus and the cochlear nucleus of the medulla oblongata (Fig. 2D). In contrast to the endogenous IGF-II expression, the hIGF-II transgene was not expressed in the meninges and the choroid plexus (Fig. 2B and E). Transcripts of the transgene were detected in the neurons of the piriform cortex (Fig. 2B), in the pyramidal and nonpyramidal neurons of the cerebral cortex layers II, III and V, and in a few cells of the granular layer of the cerebellum (Table 1). Within the medulla oblongata, the nuclei that were positive for endogenous IGF-II expression (Fig. 2D) also expressed the transgene (Fig. 2E), as detected with the SV40 probe. Moreover, the transgene is expressed in the reticular nucleus of the medulla oblongata (Fig. 2E).

Endogenous IGF-I was present in normal mice and was colocalized with the transgene in the neurons of the piriform cortex, the cerebral cortex layers II, III and V, and the above-mentioned nuclei of the medulla oblongata, 

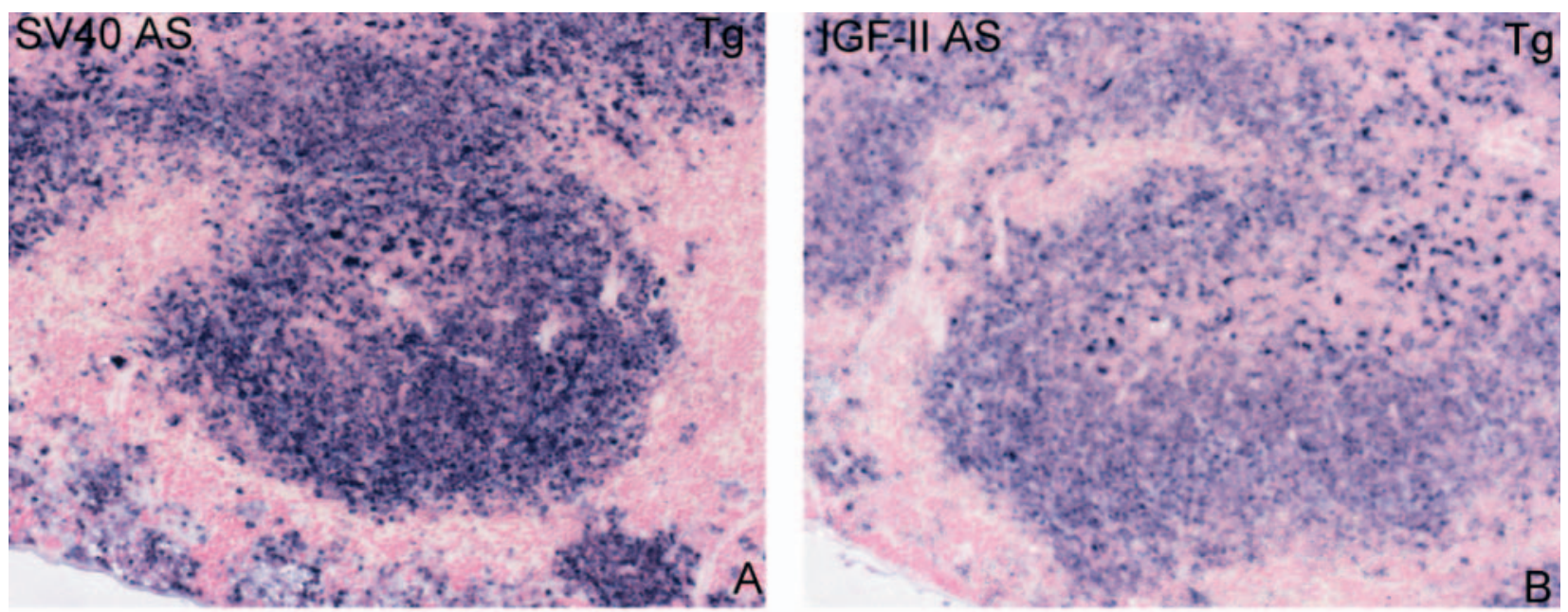

SV40 AS

FVB
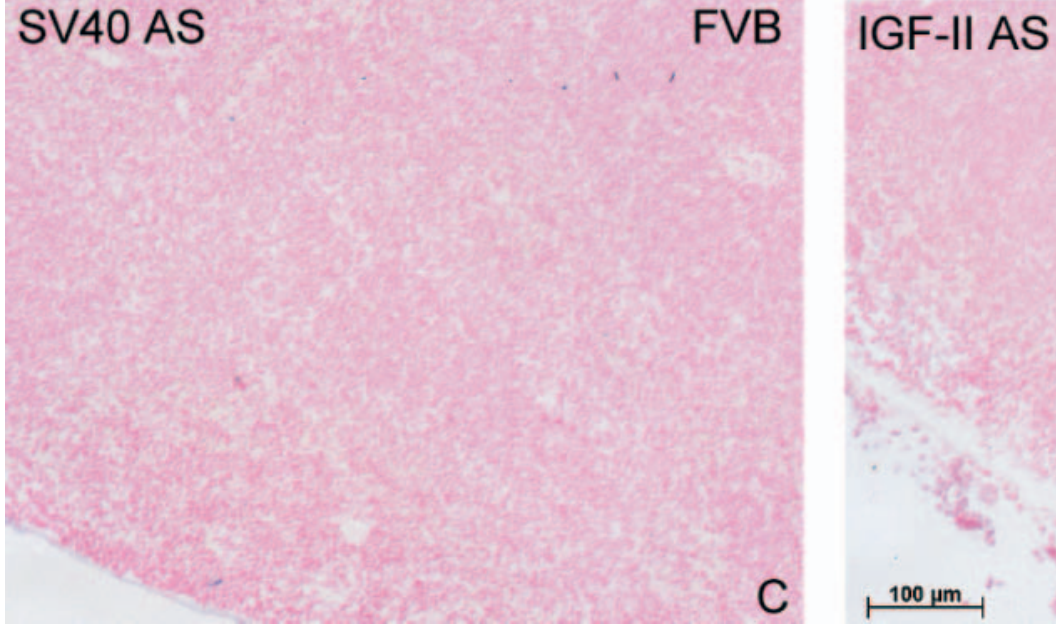

FVB

Figure 1 Expression of hIGF-II transgene and IGF-II in the spleen of prepubertal 4-week-old normal (FVB) (C and D) and hIGF-II transgenic mice (Tg) (A and B). Sections were hybridized with antisense digoxigenin-labeled cRNA probes, specific for hIGF-II transgene (A and $C$ ) and IGF-II (B and D), and visualized under bright-field illumination. The RNA signal is shown as a blue precipitate. The sections were counterstained with nuclear fast red. The scale bar represents $100 \mu \mathrm{m}(\mathrm{A}-\mathrm{D})$.

including the reticular nucleus (Fig. $2 \mathrm{G}$ and $\mathrm{H}$ ). In addition, IGF-I was expressed in the thalamus and the Purkinje cells of the cerebellum, but not in the granular layer of the cerebellum (Table 1).

Endogenous IGF-I and IGF-II expression levels were not affected by the IGF-II transgene expression, because no differences were detected between the expression in the normal and the transgenic brain (Table 1). Control hybridizations of brain sections with the corresponding sense RNA probes showed no signals (Fig. 2C, F and J).

Effects of neuronal hIGF-II overexpression on IGFBP-2, -3 and -5 expression

As the bioactivity of IGF-II can be regulated by IGFBPs, we studied the influence of hIGF-II overexpression on the localization and regulation of IGFBP-2, -3 and -5 mRNA expression. IGFBP-2 was expressed and colocalized with endogenous IGF-II in the meninges and the simple cuboidal epithelium of the choroid plexus, and lower expression was observed in the nuclei of the medulla oblongata (Fig. 3A). In contrast to IGF-II expression, IGFBP-2 was also expressed in the reticular nucleus of the medulla oblongata. Endogenous IGFBP-2 expression was detected at the expression sites of the IGF-I gene (that is, the piriform cortex, the cerebral cortex layers II, III and V, and the nuclei of the medulla oblongata). However, IGFBP-2 was not detected in the Purkinje cells of the cerebellum and in the thalamus (Table 1).

In the nuclei of the medulla oblongata, IGFBP-2 expression was upregulated by the hIGF-II transgene (Fig. 3). Quantification of IGFBP-2 expression in a defined area 


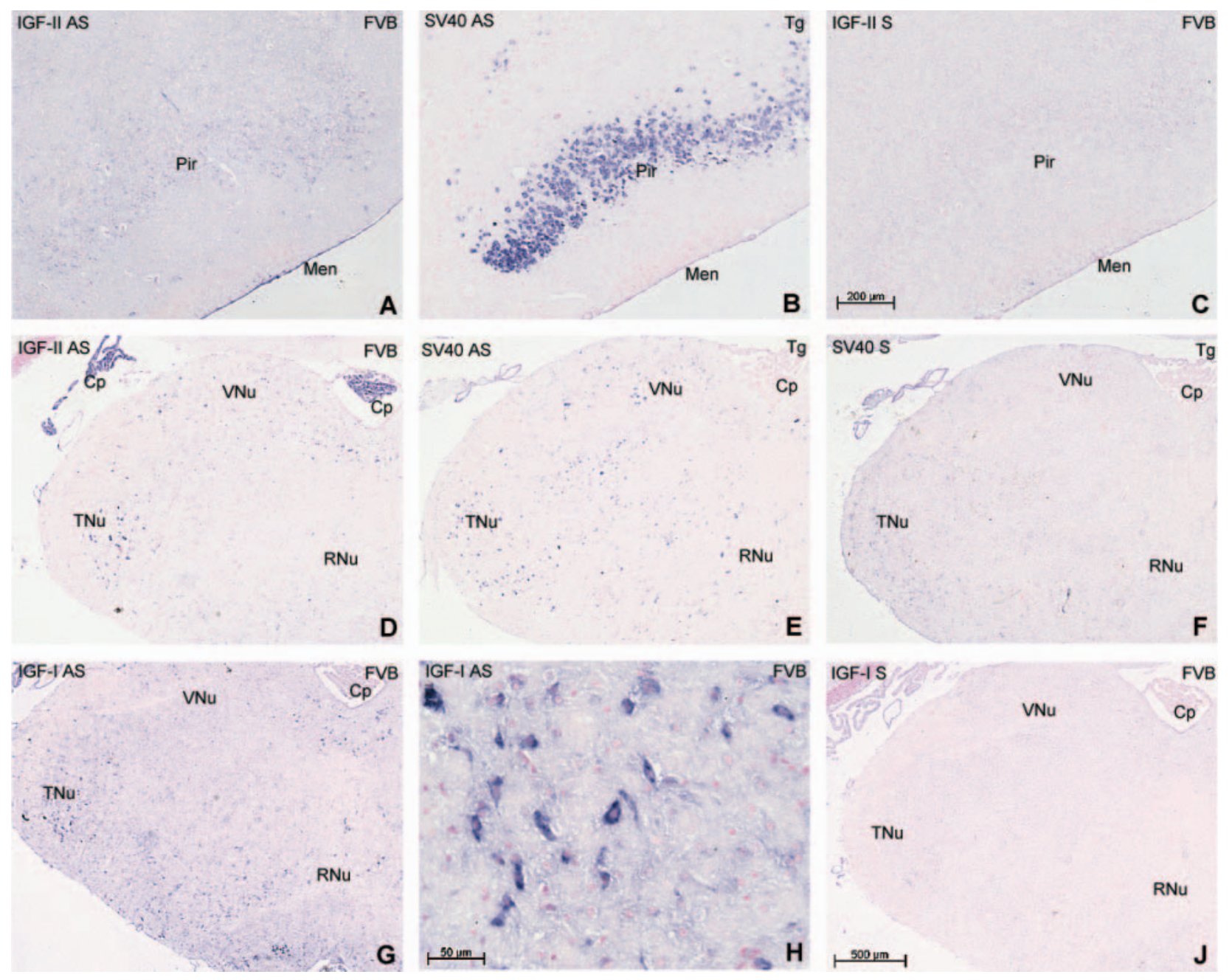

Figure 2 Expression of IGF-II, hIGF-II transgene and IGF-I in the brain of prepubertal 4-week-old normal (FVB) (A, C, D and G-J) and hIGF-II transgenic mice (Tg) (B, E and F). Sections were hybridized with antisense digoxigenin-labeled cRNA probes, specific for IGF-II (A and $D)$, hIGF-ll transgene (B and $E$ ) and IGF-I (G and $H)$, and were visualized under bright-field illumination. The RNA signal is shown as a blue precipitate. The sections were counterstained with nuclear fast red. Control sections hybridized with the sense probes showed no signal (C, F and J). The scale bars represent $200 \mu \mathrm{m}(\mathrm{A}-\mathrm{C}), 50 \mu \mathrm{m}(\mathrm{H})$ or $500 \mu \mathrm{m}(\mathrm{D}-\mathrm{G}$ and J) respectively. Men, meninges; Cp, choroid plexus; Pir, piriform cortex; TNu, trigeminal nucleus; VNu, vestibular cerebellar nucleus; RNu, reticular nucleus.

of interest within the trigeminal nucleus showed 10-fold upregulation of IGFBP-2 expression (Fig. 3E; means \pm S.E.M. are given; $1434 \pm 284(\mathrm{FVB})$ vs $13984 \pm 2084$ (Tg) IGFBP-2-positive pixels; FVB $n=4 ; \mathrm{Tg} n=5$; $P<0 \cdot 0011)$. IGFBP-2 expression levels within the other regions of the brain expressing the transgene were not affected by IGF-II overexpression (Table 1).

In contrast to the IGF-II and IGFBP-2 expression in epithelial cuboidal cells of the choroid plexus (Fig. 4A and B), IGFBP-3 and -5 expression was found in the flat epithelial cells of blood vessels present in the choroid plexus (Fig. 4C and D), which lack expression of both IGFs and the transgene. IGFBP-5 was coexpressed with the transgene and endogenous IGF-I in the piriform cortex, the cerebral cortex layers II, III and V, and the nuclei of the medulla oblongata (Table 1). In addition, IGFBP-5 was coexpressed with IGF-I within the thalamus and with the hIGF-II transgene in the granular layer of the cerebellum. IGFBP-5 was also expressed in the endothelial cells of the lateral ventricle (Table 1). No differences in expression level or expression pattern were detected between the normal and the hIGF-II transgenic mice for IGFBP-3 and -5 (Table 1). Control hybridization of brain sections with the corresponding sense RNA probes showed no signals (Fig. 3C and Fig. 4E and $\mathrm{F})$. 
Table 1 Localization of IGFs and IGFBPs mRNA expression in the brain of normal mice and changes in expression in hIGF-II transgenic mice visualized by in situ hybridization

\begin{tabular}{|c|c|c|c|c|c|c|c|}
\hline & \multicolumn{5}{|c|}{ Normal mice } & \multicolumn{2}{|l|}{ Transgenic mice } \\
\hline & IGF-I & IGF-II & IGFBP-2 & IGFBP-3 & IGFBP-5 & IGF-II transgene & IGFBP-2 \\
\hline \multicolumn{8}{|l|}{ Nonneuronal } \\
\hline Choroid plexus & - & $+^{\text {a) }}$ & $+^{a)}$ & $+^{\mathrm{b})}$ & $+^{\mathrm{b})}$ & - & $=$ \\
\hline Meninges & - & + & + & - & - & - & $=$ \\
\hline Lateral ventricle & - & - & - & - & + & - & $=$ \\
\hline \multicolumn{8}{|l|}{ Neuronal } \\
\hline Piriform cortex & + & - & + & - & + & + & $=$ \\
\hline Cerebral cortex & + & - & + & - & + & + & $=$ \\
\hline Thalamus & + & - & - & - & + & - & $=$ \\
\hline Purkinje cells & + & - & - & - & - & - & $=$ \\
\hline Granular layer & - & - & - & - & + & + & $=$ \\
\hline \multicolumn{8}{|c|}{ Nuclei of medulla oblongata } \\
\hline Cochlear & + & + & + & - & + & + & $\uparrow$ \\
\hline Interposed & + & + & + & - & + & + & $\uparrow$ \\
\hline Reticular & + & - & + & - & + & + & $\uparrow$ \\
\hline Trigeminal & + & + & + & - & + & + & $\uparrow$ \\
\hline Vestibular cerebellar & + & + & + & - & + & + & $\uparrow$ \\
\hline
\end{tabular}

+, expression; -, no expression; $\uparrow$, upregulated; $=$, no change. ${ }^{\text {a) }}$ cuboidal epithelial cells, ${ }^{\text {b)}}$ Flat epithelial cells of blood vessels.

\section{Discussion}

Expression patterns of IGF-axis components in the brain of prepubertal mice as analyzed by nonradioactive in situ hybridization

In this study, we used the nonradioactive in situ hybridization technique to detect the expression patterns of IGF-I, IGF-II and IGFBP-2, -3 and -5 in the brain of prepubertal mice. The hIGF-II transgene probe has been shown to be specific for the transgene, because no hIGFII transgene expression was observed in the spleen of normal mice when hybridized with the hIGF-II transgene antisense probe.

Endogenous IGF-II is mainly present in nonneuronal structures such as the meninges and the choroid plexus, confirming the data reported by others during rat brain development, who used radioactive in situ hybridization (Stylianopoulou et al. 1988, Bondy et al. 1990, 1992, Lee et al. 1993, Logan et al. 1994). Although IGF-II is predominantly expressed in nonneuronal cells, we also noticed that neuronal cells, specifically the nuclei of the medulla oblongata, express the endogenous IGF-II gene. This observation extends the findings of Rotwein and colleagues (1988), who found IGF-II expression in the medulla oblongata of the adult rat brain with a solutionhybridization nuclease-protection assay.

The expression pattern of IGF-I in neuronal structures such as the piriform cortex, Purkinje cells and medulla oblongata corresponds with that observed by others in rats and mice, using radioactive in situ hybridization (Bondy et al. 1992, D'Ercole et al. 1996).

With respect to the IGFBPs, detailed analysis of the expression patterns showed that the simple cuboidal epi- thelium expresses both endogenous IGF-II and IGFBP-2, whereas IGFBP-3 and -5 are expressed within the cells of the blood vessels belonging to the choroid plexus. Although IGFBP-3 expression in the choroid plexus of the intact rat brain has been reported before (Walter et al. 1997), the exact localization of the expression within the choroid plexus was not known. Our observation that both IGFBP-3 and -5 are expressed in blood vessel cells suggests that these IGFBPs play an important role in the transport of IGFs across the blood-brain barrier (Armstrong et al. 2000, Pan \& Kastin 2000), as in the local increase in IGFBP-3 within a cerebral wound, especially around blood vessels in lesioned rat brains (Walter et al. 1999). In addition, the expression of IGF-II together with IGFBP-2 suggests a role for IGFBP-2 in targeting IGF-II action in the cerebrospinal fluid (CSF) (Wood et al. 1990, Bondy et al. 1992).

\section{Topology of transgenic IGF-II expression}

Whereas endogenous IGF-II is predominantly expressed in nonneuronal cells, it is remarkable that the hIGF-II transgene is exclusively expressed in neuronal brain structures such as neuronal cells in the piriform cortex, the cerebral cortex (layers II, III and V), the medulla oblongata and the granular layer of the cerebellum. Although the expression pattern of the IGF-II transgene colocalizes for a large part with that of IGF-I in the neurons of the piriform cortex, the cerebral cortex and the medulla oblongata, IGF-I expression was also detected in the thalamus and the Purkinje cells of the cerebellum, as reported by others before using different techniques (Rotwein et al. 1988, Bondy \& Lee 1993). It has been 

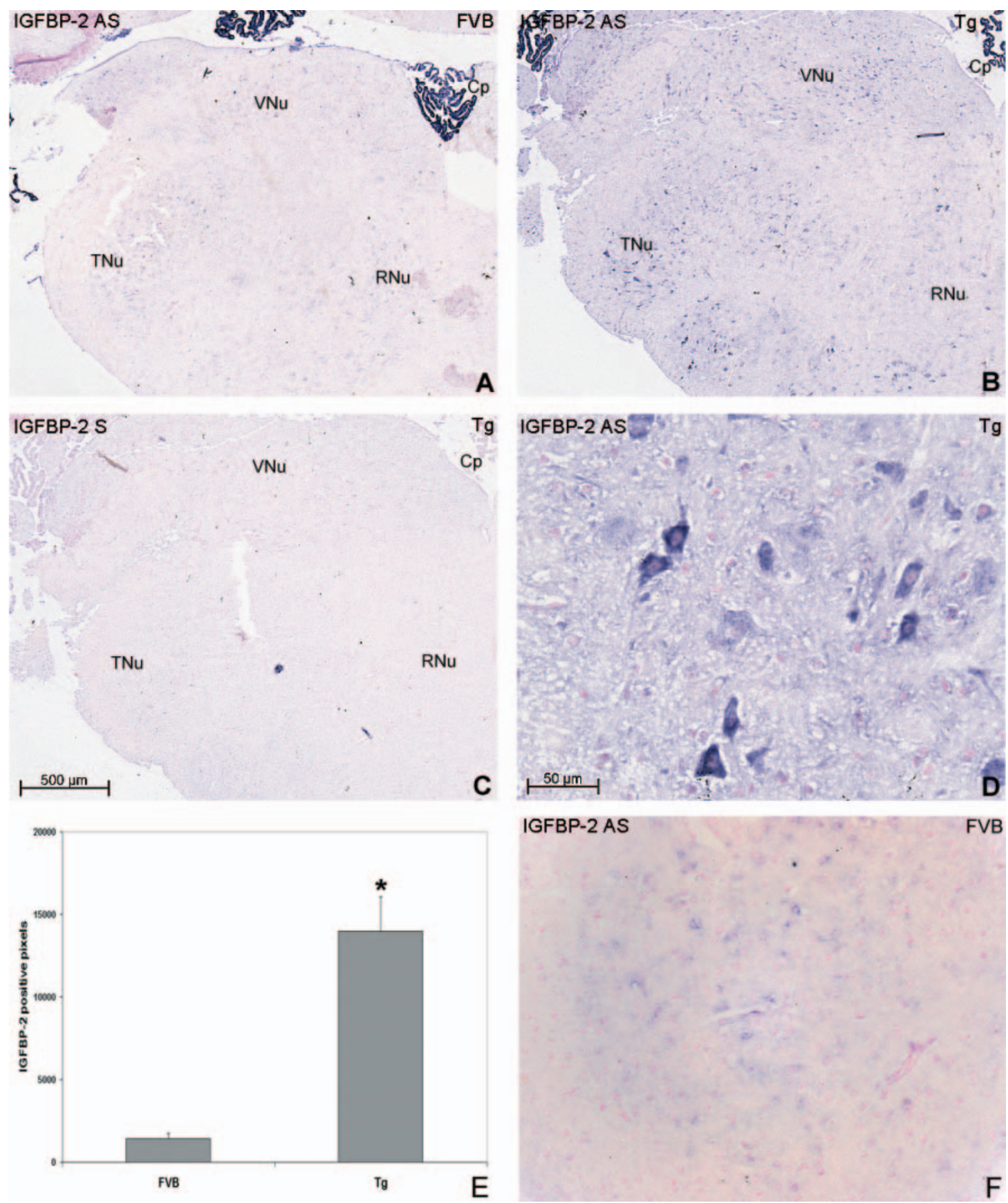

Figure 3 Influence of hIGF-II transgene on IGFBP-2 expression in medulla oblongata. IGFBP-2 expression in prepubertal normal mice (FVB) (A and F) and hIGF-II-transgenic mice (Tg) (B and D). The RNA signal is shown as a blue precipitate. The sections were counterstained with nuclear fast red. Control sections hybridized with the sense probe showed no signal (C). The scale bars represent $500 \mu \mathrm{m}(\mathrm{A}-\mathrm{C})$ or $50 \mu \mathrm{m}$ (D and F) respectively. (E) Tenfold IGFBP-2 upregulation in the trigeminal nucleus of transgene mice depicted as total positive pixels within the measured area (means \pm S.E.M. are given; $1434 \pm 284$ (FVB) vs $13984 \pm 2084$ (Tg) IGFBP-2 positive pixels; FVB $n=4$; Tg $n=5 ;{ }^{*} P<0 \cdot 0011$ ). Cp, choroid plexus; TNu, trigeminal nucleus; $\mathrm{VNu}$, vestibular cerebellar nucleus; $\mathrm{RNu}$, reticular nucleus. 

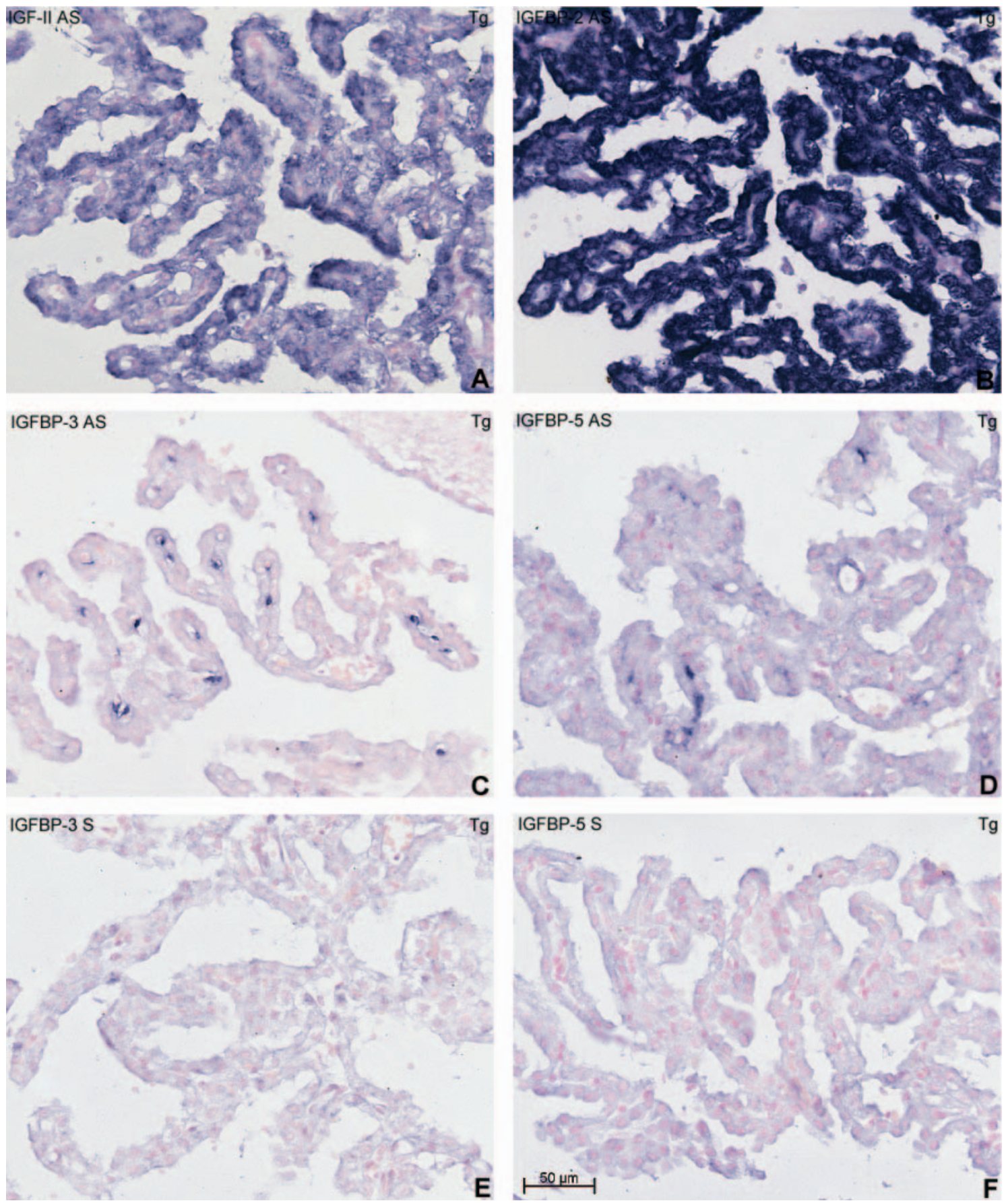

Figure 4 IGFBP-2, -3 and -5 expression in the choroid plexus of prepubertal 4-week-old hIGF-II-transgenic mice (Tg). Sections were hybridized with antisense digoxigenin-labeled cRNA probes, specific for IGF-II (A), IGFBP-2 (B), IGFBP-3 (C) and IGFBP-5 (D), and were visualized under bright-field illumination. The RNA signal is shown as a blue precipitate. The sections were counterstained with nuclear fast red. Control sections hybridized with the sense probes showed no signal ( $E$ and $F)$. The scale bar represents $50 \mu \mathrm{m}(\mathrm{F})$. The magnification of each panel is equal.

shown in vitro that IGF-II can stimulate the proliferation of neuronal cells and supporting glial cells (Enberg et al. 1985, Lim et al. 1985) as well as the neurite outgrowth
(Recio-Pinto et al. 1986). Thus, the hIGF-II produced within the neuronal cells might be able to mimic the actions of IGF-I. 
It has been reported by several authors that the use of different promoters can display ectopic expression of different transgenes in vivo (Swanson et al. 1985, Kondoh et al. 1987, Russo et al. 1988). In this study, we show ectopic expression of the IGF-II transgene to be under the control of the $\mathrm{H}-2 \mathrm{~K}^{\mathrm{b}}$ promoter in neuronal cells of specific brain areas, places where normally IGF-II and $\mathrm{H}-2 \mathrm{~K}^{\mathrm{b}}$ do not occur (Ruther et al. 1988, Drezen et al. 1992). This is probably due to the site of integration of the transgene in the genome, since only one of the three founders expressed IGF-II in areas in the brain, where normally IGF-II and $\mathrm{H}-2 \mathrm{~K}^{\mathrm{b}}$ are not expressed (van Buul-Offers et al. 1995). This ectopic IGF-II expression contrasts with the IGF-I expression as observed in IGF-I transgenic mice. When IGF-I is under the control of either the IGF-II promoter or the MT promoter, the expression pattern of the transgene is identical with that obtained for endogenous IGF-I (Ye et al. 1996).

\section{Changes in IGF-axis components upon hIGF-II overexpression}

Although the hIGF-II gene is expressed in considerable amounts in neuronal cells of the cortex and the piriform cortex, this did not affect the endogenous IGF-I and/or IGF-II expression levels in these areas. Nor did IGF-II overexpression in the brain affect the growth of the brain during postnatal growth (van Buul-Offers et al. 1995). This contrasts with the increased growth of the brain in IGF-I transgenic mice (Ye et al. 1996), suggesting that IGF-II is much less important for brain growth than IGF-I (Carson et al. 1993, Ye et al. 1995).

The biologic activity of IGFs is largely dependent on the presence of IGFBPs (Firth \& Baxter 2002). It has been suggested by Smink and coauthors that the absence of increased growth induced by IGF-II overexpression in the spleen of our transgenic mice was caused by an increase in IGFBP-2, -3 and -5 expression. In contrast, the thymus showed overgrowth, but no upregulation of these IGFBPs (Smink et al. 1999). In the brain of these mice, however, only an upregulation of IGFBP-2 expression became apparent in the nuclei of the medulla oblongata, with a 10-fold IGFBP-2 upregulation in the trigeminal nucleus, without any consequences for brain growth. This again shows the tissue dependency of the actions of the IGFs and their binding proteins.

In normal mice, a strictly positive relationship exists between the spatial distribution of IGF-II and IGFBP-2 expression within the choroid plexus and the meninges (Lee et al. 1993). Also after brain injury in the rat, an increased IGF-II and IGFBP-2 expression has been observed within the choroid plexus together with an increased secretion within the CSF (Walter et al. 1999). In the neuronal structures expressing the IGF-II transgene, upregulation of IGFBP-2 could be detected only in the nuclei of the medulla oblongata, with a 10-fold IGFBP-2 upregulation in the trigeminal nucleus, but no upregulation occurred in the piriform and cerebral cortex. Such a difference in upregulation between IGF-II and IGFBP-2 in the different brain areas consisting of neuronal cells has not been observed before, and it suggests at least that different regulatory mechanisms play a role in gene regulation of IGF-II and IGFBP-2.

IGFBP-5 is present within neuronal cells at high concentrations, managing IGF-I activity (Leventhal et al. 1999). The positive relationship between IGFBP-5 and IGF-I activity manifests itself in the decreased IGFBP-5 expression concurrent with the decrease in IGF-I expression in neuronal cells after brain injury induced by hypoxic-ischemia (Clawson et al. 1999) and the increased IGFBP-5 expression in brain tissue overexpressing the IGF-I gene (Ye \& D'Ercole 1998). Although the hIGF-II transgene is expressed at high levels in neuronal cells and can bind IGFBP-5 with an even higher affinity than IGF-I (Jones \& Clemmons 1995), it does not influence its expression. This suggests that IGF-II may not be an important regulator of IGFBP-5 expression in vivo, in contrast to IGF-I, which upregulates IGFBP-5 in the brain of adult mice (Ye et al. 1996, Ye \& D’Ercole 1998).

In summary, we can conclude that, in contrast to endogenous IGF-II, which is predominantly expressed in nonneuronal structures, the IGF-II transgene is exclusively expressed in neuronal cells. Furthermore, the transgene affects neither the expression of endogenous IGF-I and IGF-II, nor that of IGFBP-3 and -5 . However, the IGFBP-2 expression in the nuclei of the medulla oblongata is upregulated by the IGF-II transgene, with a 10 -fold IGFBP-2 upregulation in the trigeminal nucleus, suggesting that IGFBP-2 can modulate IGF-II action in neuronal cells.

\section{Acknowledgements}

Thanks are due to Michiel Nijdam and Patricia Spijkers for preliminary experiments, Ria Gresnigt for taking care of the animals and Dr Joost Koedam for his help in quantifying the in situ hydrization data.

\section{References}

Armstrong CS, Wuarin L \& Ishii DN 2000 Uptake of circulating insulin-like growth factor-I into the cerebrospinal fluid of normal and diabetic rats and normalization of IGF-II mRNA content in diabetic rat brain. Journal of Neuroscience Research 59 649-660.

Beilharz EJ, Bassett NS, Sirimanne ES, Williams CE \& Gluckman PD 1995 Insulin-like growth factor II is induced during wound repair following hypoxic-ischemic injury in the developing rat brain. Molecular Brain Research 29 81-91.

Bondy C \& Lee WH 1993 Correlation between insulin-like growth factor (IGF)-binding protein 5 and IGF-I gene expression during brain development. Journal of Neuroscience 13 5092-5104. 
Bondy CA, Werner H, Roberts CT Jr \& LeRoith D 1990 Cellular pattern of insulin-like growth factor-I (IGF-I) and type I IGF receptor gene expression in early organogenesis: comparison with IGF-II gene expression. Molecular Endocrinology 4 1386-1398.

Bondy C, Werner H, Roberts CT Jr \& LeRoith D 1992 Cellular pattern of type-I insulin-like growth factor receptor gene expression during maturation of the rat brain: comparison with insulin-like growth factors I and II. Neuroscience 46 909-923.

Carson MJ, Behringer RR, Brinster RL \& McMorris FA 1993 Insulin-like growth factor I increases brain growth and central nervous system myelination in transgenic mice. Neuron $\mathbf{1 0}$ 729-740.

Clawson TF, Vannucci SJ, Wang GM, Seaman LB, Yang XL \& Lee WH 1999 Hypoxia-ischemia-induced apoptotic cell death correlates with IGF-I mRNA decrease in neonatal rat brain. Biological Signals and Receptors 8 281-293.

D’Ercole AJ, Ye P, Calikoglu AS \& Gutierrez-Ospina G 1996 The role of the insulin-like growth factors in the central nervous system. Molecular Neurobiology 13 227-255.

De Block M \& Debrouwer D 1993 RNA-RNA in situ hybridization using digoxigenin-labeled probes: the use of high-molecular-weight polyvinyl alcohol in the alkaline phosphatase indoxyl-nitroblue tetrazolium reaction. Analytical Biochemistry 215 86-89.

Drezen JM, Nouvel P, Babinet C \& Morello D 1992 Different regulation of class I gene expression in the adult mouse and during development. Journal of Immunology 149 429-437.

Enberg G, Tham A \& Sara VR 1985 The influence of purified somatomedins and insulin on foetal rat brain DNA synthesis in vitro. Acta Physiologica Scandinavica 125 305-308.

Firth SM \& Baxter RC 2002 Cellular actions of the insulin-like growth factor binding proteins. Endocrine Reviews 23 824-854.

Franklin KBJ \& Paxinos G 1997 The Mouse Brain Stereotaxic Coordinates. New York: Academic Press.

Guan J, Williams CE, Skinner SJ, Mallard EC \& Gluckman PD 1996 The effects of insulin-like growth factor (IGF)-1, IGF-2, and des-IGF-1 on neuronal loss after hypoxic-ischemic brain injury in adult rats: evidence for a role for IGF binding proteins. Endocrinology 137 893-898.

Jansen M, van Schaik FM, Ricker AT, Bullock B, Woods DE, Gabbay KH, Nussbaum AL, Sussenbach JS \& van den Brande JL 1983 Sequence of cDNA encoding human insulin-like growth factor I precursor. Nature 306 609-611.

Jansen M, van Schaik FM, van Tol H, van den Brande JL \& Sussenbach JS 1985 Nucleotide sequences of cDNAs encoding precursors of human insulin-like growth factor II (IGF-II) and an IGF-II variant. FEBS Letters 179 243-246.

Jones JI \& Clemmons DR 1995 Insulin-like growth factors and their binding proteins: biological actions. Endocrine Reviews 16 3-34.

Kawamura S \& Niimi K 1972 Counterstaining of Nauta-Gygaximpregnated sections with cresyl violet. Stain Technology 47 1-6.

Kondoh H, Katoh K, Takahashi Y, Fujisawa H, Yokoyama M, Kimura S, Katsuki M, Saito M, Nomura T \& Hiramoto Y 1987 Specific expression of the chicken delta-crystallin gene in the lens and the pyramidal neurons of the piriform cortex in transgenic mice. Developmental Biology 120 177-185.

Lee WH, Michels KM \& Bondy CA 1993 Localization of insulin-like growth factor binding protein-2 messenger RNA during postnatal brain development: correlation with insulin-like growth factors I and II. Neuroscience 53 251-265.

Leventhal PS, Russel JW \& Feldman EL 1999 IGFs and the nervous system. In The IGF System, pp 425-455. Eds RG Rosenfeld \& CT Roberts. Portland, OR: Humana Press.

Lim R, Miller JF, Hicklin DJ, Holm AC \& Ginsberg BH 1985 Mitogenic activity of glia maturation factor. Interaction with insulin and insulin-like growth factor-II. Experimental Cell Research 159 335-343.
Logan A, Gonzalez AM, Hill DJ, Berry M, Gregson NA \& Baird A 1994 Coordinated pattern of expression and localization of insulin-like growth factor-II (IGF-II) and IGF-binding protein-2 in the adult rat brain. Endocrinology 135 2255-2264.

Melton DA, Krieg PA, Rebagliati MR, Maniatis T, Zinn K \& Green MR 1984 Efficient in vitro synthesis of biologically active RNA and RNA hybridization probes from plasmids containing a bacteriophage SP6 promoter. Nucleic Acids Research 12 7035-7056.

Naeve GS, Vana AM, Eggold JR, Verge G, Ling N \& Foster AC 2000 Expression of rat insulin-like growth factor binding protein-6 in the brain, spinal cord, and sensory ganglia. Molecular Brain Research 75 185-197.

Pan W \& Kastin AJ 2000 Interactions of IGF-1 with the blood-brain barrier in vivo and in situ. Neuroendocrinology 72 171-178.

Recio-Pinto E, Rechler MM \& Ishii DN 1986 Effects of insulin, insulin-like growth factor-II, and nerve growth factor on neurite formation and survival in cultured sympathetic and sensory neurons. Journal of Neuroscience 6 1211-1219.

Rotwein P, Burgess SK, Milbrandt JD \& Krause JE 1988 Differential expression of insulin-like growth factor genes in rat central nervous system. PNAS 85 265- 269.

Russo AF, Crenshaw EB III, Lira SA, Simmons DM, Swanson LW \& Rosenfeld MG 1988 Neuronal expression of chimeric genes in transgenic mice. Neuron 1 311-320.

Ruther U, Muller W, Sumida T, Tokuhisa T, Rajewsky K \& Wagner EF 1988 c-fos expression interferes with thymus development in transgenic mice. Cell $\mathbf{5 3} 847-856$.

Schuller AG, Zwarthoff EC \& Drop SL 1993 Gene expression of the six insulin-like growth factor binding proteins in the mouse conceptus during mid- and late gestation. Endocrinology 132 2544-2550.

Smink JJ, Koster JG, Hendriks-Stegeman BI \& van Buul-Offers SC 1999 Insulin-like growth factor (IGF) II induced changes in expression of IGF binding proteins in lymphoid tissues of hIGF-II transgenic mice. Endocrinology 140 5876-5882.

Smink JJ, Koster JG, Gresnigt MG, Rooman R, Koedam JA \& van Buul-Offers SC 2002 IGF and IGF-binding protein expression in the growth plate of normal, dexamethasone-treated and human IGF-II transgenic mice. Journal of Endocrinology 175 143-153.

Stylianopoulou F, Herbert J, Soares MB \& Efstratiadis A 1988 Expression of the insulin-like growth factor II gene in the choroid plexus and the leptomeninges of the adult rat central nervous system. PNAS 85 141-145.

Swanson LW, Simmons DM, Arriza J, Hammer R, Brinster R, Rosenfeld MG \& Evans RM 1985 Novel developmental specificity in the nervous system of transgenic animals expressing growth hormone fusion genes. Nature 317 363-366.

van Buul-Offers SC, de Haan K, Reijnen-Gresnigt MG, Meinsma D, Jansen M, Oei SL, Bonte EJ, Sussenbach JS \& van den Brande JL 1995 Overexpression of human insulin-like growth factor-II in transgenic mice causes increased growth of the thymus. Journal of Endocrinology 144 491-502.

van Kleffens M, Lindenbergh-Kortleve DJ, Koster JG, van Neck JW, Flyvbjerg A, Rasch R, Drop SL \& van Buul-Offers SC 2001 The role of the IGF axis in IGFBP-1 and IGF-I induced renal enlargement in Snell dwarf mice. Journal of Endocrinology $\mathbf{1 7 0}$ 333-346.

Walter HJ, Berry M, Hill DJ \& Logan A 1997 Spatial and temporal changes in the insulin-like growth factor (IGF) axis indicate autocrine/paracrine actions of IGF-I within wounds of the rat brain. Endocrinology 138 3024-3034.

Walter HJ, Berry M, Hill DJ, Cwyfan-Hughes S, Holly JM \& Logan A 1999 Distinct sites of insulin-like growth factor (IGF)-II expression and localization in lesioned rat brain: possible roles of IGF binding proteins (IGFBPs) in the mediation of IGF-II activity. Endocrinology 140 520-532.

Wilkinson DG 1992 In Situ Hybridization: A Practical Approach. Oxford: Oxford University Press. 
Wood TL, Brown AL, Rechler MM \& Pintar JE 1990 The expression pattern of an insulin-like growth factor (IGF)-binding protein gene is distinct from IGF-II in the midgestational rat embryo. Molecular Endocrinology 4 1257-1263.

Ye P \& D’Ercole J 1998 Insulin-like growth factor I (IGF-I) regulates IGF binding protein-5 gene expression in the brain. Endocrinology $13965-71$

Ye P, Carson J \& D’Ercole AJ 1995 In vivo actions of insulin-like growth factor-I (IGF-I) on brain myelination: studies of IGF-I and IGF binding protein-1 (IGFBP-1) transgenic mice. Journal of Neuroscience 15 7344-7356.
Ye P, Xing Y, Dai Z \& D'Ercole AJ 1996 In vivo actions of insulin-like growth factor-I (IGF-I) on cerebellum development in transgenic mice: evidence that IGF-I increases proliferation of granule cell progenitors. Developmental Brain Research 95 44-54.

Received 14 May 2004

Accepted 27 May 2004

Made available online as an

Accepted Preprint 4 June 2004 